DOI 10.18551/rjoas.2021-09.18

\title{
INORGANIC FERTILIZERS COVERED BY ACTIVE RICE HUSK CHARCOAL PROMOTE GROWTH AND YIELD OF SHALLOT IN DRYLAND
}

\author{
Sugianti Titin, Hidayah Baiq Nurul ${ }^{\star}$ \\ Institute for Assessment of Agricultural Technology (Balai Pengkajian Teknologi Pertanian), \\ West Nusa Tenggara Province, Indonesia \\ *E-mail: nurul.murdoch@gmail.com
}

\begin{abstract}
Shallot is one of the seven strategic commodities in Indonesia. The demand for shallot continues to increase every year as the population increases, therefore the expansion of shallot planting areas in dryland is an alternative to increase production. This study aims to investigate the response of growth and yield of shallot (Batu ljo variety) to various doses of inorganic fertilizers coated with activated charcoal in dryland. This research was conducted at the Sandubaya Experimental Station - West Nusa Tenggara Institute for Assessment of Agricultural Technology from March to June 2019. The research location is at the coordinates of $-8^{\circ} 30^{\prime} 47,116^{\circ} 39^{\prime} 14,56.4 \mathrm{ft}$ at an altitude of $46.0 \mathrm{~m}$ above sea level. The study used a randomized block design (RBD) with 1 factor and 5 levels of treatment dose of inorganic fertilizer coated with activated charcoal. Treatment of inorganic fertilizer dosage, namely B1: farmer practices of inorganic fertilizer (100\%), B2: inorganic fertilizer $25 \%+$ coated with activated charcoal, B3: inorganic fertilizer $50 \%$ + coated with activated charcoal, B4: $75 \%$ inorganic fertilizer + coated with activated charcoal and B5: 100\% inorganic fertilizer + coated with activated charcoal. The results showed that there was a correlation between plant height, number of leaves, number of bulbs and yields. The application of inorganic fertilizer as much as $75 \%$ of the standard dose + activated charcoal coating can have the highest effect on plant height, number of leaves, number of bulbs, yield and weight of the shelf life of 30 to 60 days after harvesting.
\end{abstract}

\section{KEY WORDS}

Activated charcoal coated, dosage, inorganic fertilizer, shallot.

Horticulture is one of the important sub-sectors in agricultural development (Dahlianah, 2018). Shallot (Allium ascalonicum L.) is one of the horticultural commodities that belong to the spice vegetable group and is used as food seasonings (Fajar et al., 2019). The extensification of shallot continues to increase from year to year as the market share is always open and the selling price is relatively profitable for farmers (Suriadi, 2018). Considering that shallot is one of the national strategic commodities in Indonesia, it must be developed through various efforts including the use of marginal lands (Firmansyah and Mokhtar, 2014).

One of the factors that determine the success of an agricultural system is land resources, because almost all cultivation businesses are based on land resources, but the current problem is the low level of soil fertility, especially on marginal lands (Gusmailina et al., 2015). One of the efforts to fulfill soil fertility is by means of fertilization. Fertilization is an important factor affecting plant growth in agricultural cultivation systems. The nutrients contained in the soil alone are not sufficient for optimal plant growth, but excessive application of inorganic fertilizers can result in decreased of land productivity.

One way to overcome the further impacts that will arise from the use of inorganic fertilizers is through the application of inorganic fertilizers with the right dose (Anonymous, 2016). In addition to the right dose of fertilization, technological innovation is needed in fertilization activities so that it is hoped that the effect of applying fertilizer can be seen on its effect on growth and increased production of shallot. The use of inorganic fertilizers besides being able to reduce land productivity, the problem faced by farmers is also the nature of fertilizers that are easily soluble so that excessive fertilizer application becomes ineffective. 
One way to modify slow availability of fertilizer is to mix materials that are difficult to dissolve in water and coat the fertilizer with certain materials so that the release of fertilizer in the soil becomes slow (Pratomo et al., 2009). Fertilizers in the form of slow release can optimize nitrogen absorption because they can control the release of nitrogen elements according to the time and amount needed and can maintain the presence of nitrogen in the soil (Nainggolan et al., 2009). Activated charcoal is a material that is difficult to dissolve in water so it can be used as a mixture for the slow release of fertilizers.

Based on these thoughts, it is necessary to do research on the application of activated charcoal in the cultivation of shallot crops. Reducing the use of inorganic fertilizers combined with activated charcoal coating on inorganic fertilizers is expected to provide new information on the use of activated charcoal in shallot cultivation, especially in dryland.

\section{MATERIALS AND METHODS OF RESEARCH}

This research was conducted at the IP2TP Sandubaya Experimental Station - West Nusa Tenggara Institute for Assessment of Agricultural Technology, Indonesia from March to June 2019. The experimental station is located at the coordinates of $8^{\circ} 30^{\prime} 47,116^{\circ} 39^{\prime} 14$, $56.4 \mathrm{ft}$ at an altitude of $46,0 \mathrm{~m}$ above sea level ( $\mathrm{m}$ asl). The shallot variety planted was local Indonesian Batu ljo variety using a 1 factor Randomized Complete Design (RCD) with 5 levels of treatment with doses of inorganic fertilizers coated with activated charcoal and replicated 3 times. Each treatment observed 7 sample plants which were selected randomly following a zig-zag pattern. The treatments studied were as follows:

- B1: $100 \%$ Inorganic Fertilizer;

- B2: $25 \%$ Inorganic Fertilizer + Activated Charcoal;

- B3: $50 \%$ Inorganic Fertilizer + Activated Charcoal;

- B4: 75\% Inorganic Fertilizer + Activated Charcoal;

- B5: $100 \%$ Inorganic Fertilizer + Activated Charcoal.

The field experiment was includes land clearing, making beds and arranging drainage channels by hoeing. Soil preparation at the experimental site was carried out by first cleaning the remaining weeds or previously planted plants, then the soil was processed by hoeing until loose. After that, an experimental plot was made with a bed size of $5 \times 1.20 \mathrm{~m}$ with a height of $20-30 \mathrm{~cm}$ and a distance between beds of $40 \mathrm{~cm}$. Fertilizer application was done by spreading it over the surface of the bed. The application of SP-36 fertilizer coated with husk charcoal was given at the time of land preparation, while for Urea and NPK fertilizers coated with husk charcoal were applied 3 times at the age of 15, 30 and 45 days after sowing (DAS). Basic fertilizer in the form of SP-36 fertilizer as much as $100 \mathrm{~kg} / \mathrm{ha}$ coated with activated charcoal was applied 7 days before sowing. NPK plus Zn fertilizer as much as 250 $\mathrm{kg} / \mathrm{ha}$ and Urea fertilizer as much as $300 \mathrm{~kg} / \mathrm{ha}$ coated with activated charcoal were given at the age of 15,30 and 45 DAS. Before the shallot bulbs were planted, the bulbs were treated by cutting off the ends $1 / 3$ of the bulb and coated with fungicide. Fertilization dose treatment on shallot plants is shown in Table 1.

Tabel 1 - Treatment of fertilization dose on shallot in dryland of Eastern Lombok, Indonesia during 2019 growing season

\begin{tabular}{lccccc}
\hline \multicolumn{1}{c}{ Fertilizer } & B1 (Farmers' Existing Application) & B2 & B3 & B4 & B5 \\
& $--------k g / h a--------$ & & & & \\
\hline Urea & 300 & 75 & 150 & 225 & 300 \\
NPK Plus Zn & 250 & 62.5 & 125 & 187.5 & 250 \\
SP-36 & 100 & $25 \sqrt{ }$ & 50 & 75 & 100 \\
Activated charcoal & - & $\sqrt{ }$ & $\sqrt{ }$ & $\sqrt{ }$ \\
\hline
\end{tabular}

Sowing activities were conducted by hand with a depth of $3-5 \mathrm{~cm}$ and planted one tuber/hole with a spacing of $20 \times 15 \mathrm{~cm}$. Plant maintenance includes weeding which was done 2 times, irrigation was done 2 times/7 days by flooding for 1 night (depending on the availability of water in the experimental site which is dryland), fertilization at the age of plants 
15, 30 and 45 days after sowing (DAS). Pest and disease control according to the level of attack in the field. Parameters observed included plant height, number of leaves, fresh weight, and weight loss after harvest. Plant height were masured from the base of the stem to the tip of the highest leaf which was straightened vertically upwards. Plant height was measured at the age of 20 and 70 DAS. The number of leaves was measured by counting the number of leaves per plant in each treatment and the number of bulbs was calculated at the age of 20 and 70 DAS. The parameters of fresh weight of sampling plots were measured at 70 DAS (at harvest), the shrinkage weight of shallot bulbs at 30 and 60 days after harvest (DAS) by drying. To find out the differences between treatments in this test, all the data that had been collected were analyzed using ANOVA and followed by an honest real difference test at the $5 \%$ level.

\section{RESULTS AND DISCUSSION}

General Characteristics of Experimental Site. The experimental site has a flat topography with a height of $46.0 \mathrm{~m}$ above sea level ( $\mathrm{m}$ asl) which is located in Labuhan Haji Village, Pringgabaya District, East Lombok Regency, West Nusa Tenggara Province, Indonesia. The results of soil analysis which was conducted previously before experiment is presented in Table 2. These results indicate that the soil pH is neutral. Neutral soil pH conditions are ideal soil conditions for plant growth. The total NPK nutrient content in the soil is very low, but the $\mathrm{P}$ and $\mathrm{K}$ nutrients available in the soil are very high. According to Bouajila and Sanaa (2011), the availability of $\mathrm{P}$ in the soil is influenced by $\mathrm{pH}$, and the highest $\mathrm{P}$ availability is at $\mathrm{pH}$ 6.8-7.2.

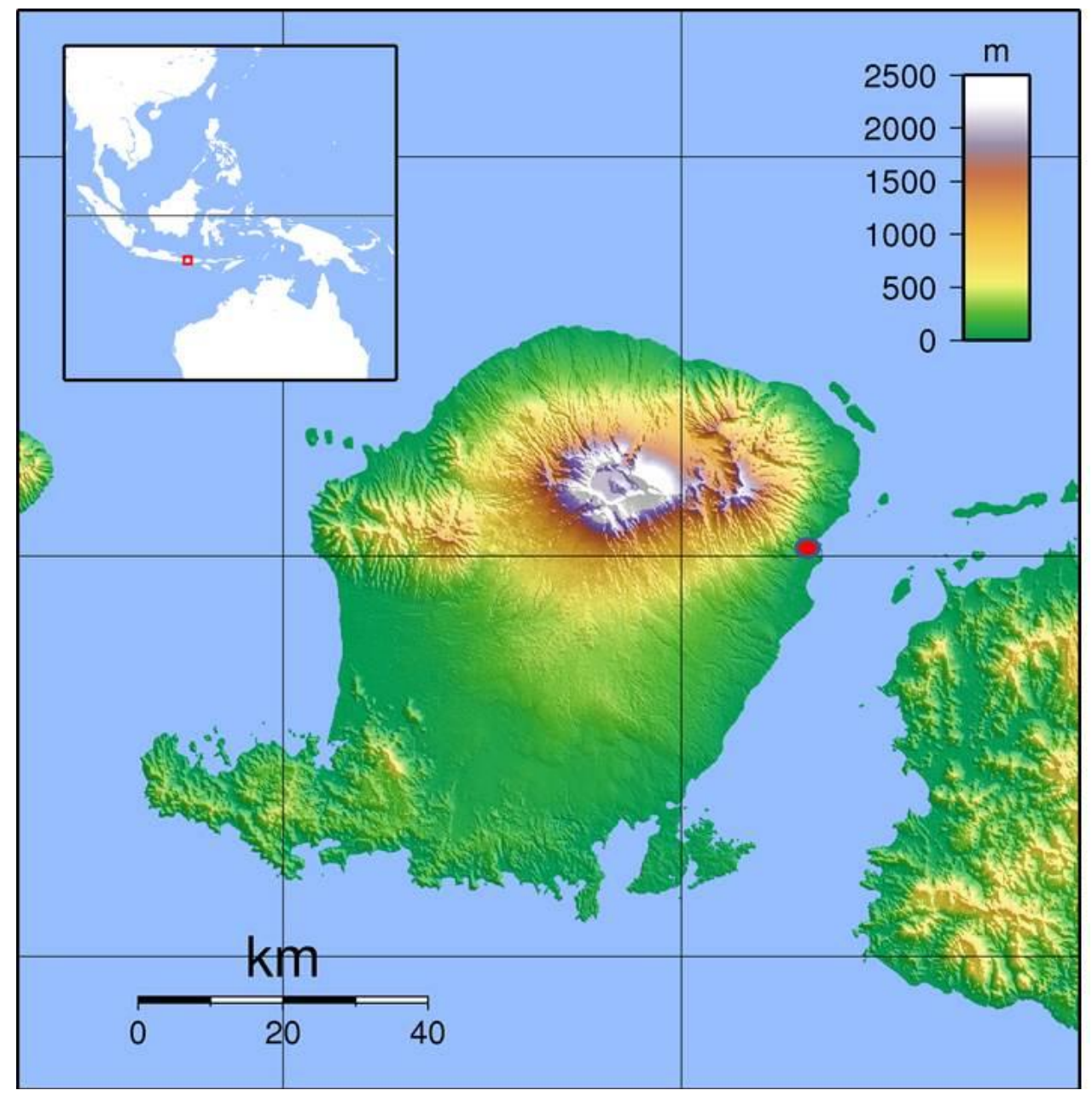

Figure 1 - Map of Lombok Island where the experimental site is in Labuhan Haji Village, East Lombok Regency, West Nusa Tenggara Province, Indonesia with red dot sign in the eastern part of the map 
Tablel 2 - Results of preliminary soil analysis at the experimental site in $\left.2019^{*}\right)$

\begin{tabular}{lcccc}
\hline \multicolumn{1}{c}{ Parameter Analysis } & Unit & Value & Status & Method \\
\hline $\mathrm{pH}-\mathrm{H}_{2} \mathrm{O}$ & - & 8.14 & Slightly alkaline & Electrode $\mathrm{pH}-$ Meter \\
$\mathrm{N} \mathrm{Total}$ & $\%$ & 0.11 & Very low & Kjeldahl \\
$\mathrm{P}$ Total & $\%$ & 0.05 & Very low & Spectrophotometer \\
$\mathrm{K}$ Total & $\%$ & 0.45 & Very low & AAS \\
$\mathrm{P}$ available & $\mathrm{ppm}$ & 23.97 & Very high & Spectrophotometer \\
$\mathrm{K}$ available & $\mathrm{ppm}$ & 101.31 & Very high & AAS \\
$\mathrm{CEC}$ & $\mathrm{cmol} / \mathrm{kg}$ & 16.26 & Low & Percolation \\
\hline
\end{tabular}

*) Based on the Soil, Fertilizer and Plant Analysis Manual, Indonesian Soil Research Institute, 2009.

Cation Exchange Capacity (CEC) at the experimental site is low with a value of 16.26 $\mathrm{cmol} / \mathrm{kg}$ but still above the average CEC for sandy soils, which is generally $2-4 \mathrm{cmol} / \mathrm{kg}$ (Ashari, 1995). Factors that can increase CEC are based on the amount of clay and organic matter (Darlita et al., 2017). The very low C-organic content of the soil affects the CEC value of the soil. Sulastri (2006) stated that CEC in general can provide an overview of the amount of soil cations in available form that can be utilized by plants.

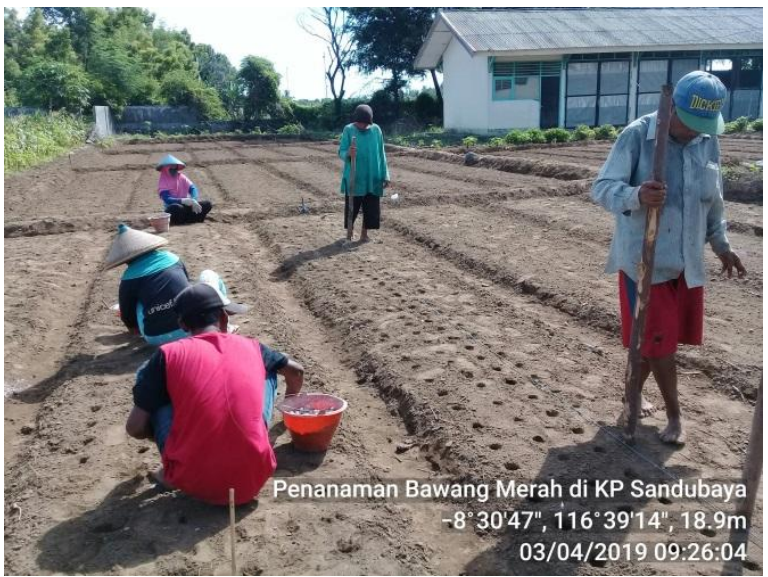

Figure 2 - Shallot sowing activities in the experimental site on $3^{\text {rd }}$ April 2019

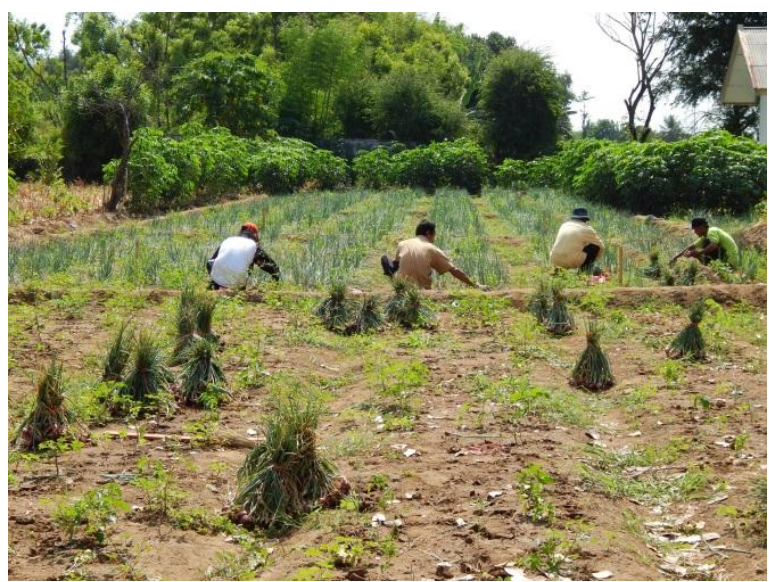

Figure 4 - Harvesting activities of shallot in the experimental site 70 days after sowing

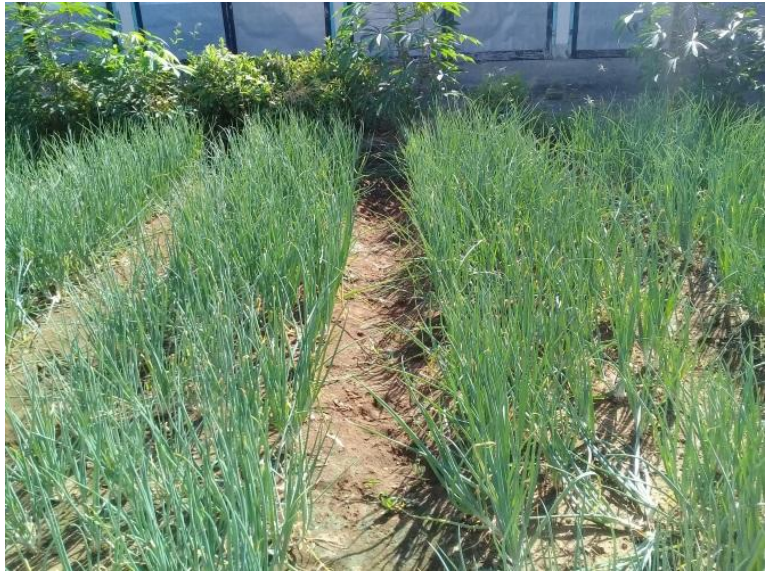

Figure 3 - Growth performance of shallot in the experimental site during the growing season in 2019
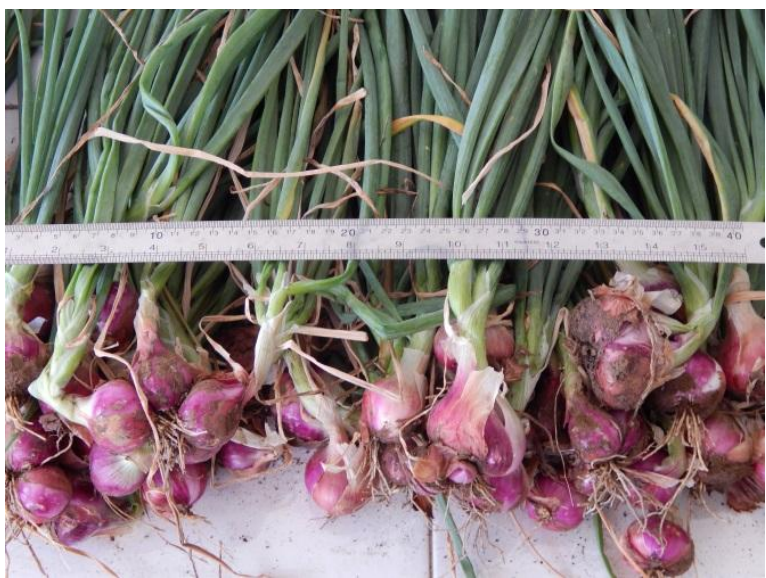

Figure 5 - Bulbs of shallot harvested from the experimental site during the growing season in 2019

Plant Height and Number of Leaves. Parameter of plant height was measured in $\mathrm{cm}$ from the soil surface to the tip of the highest leaf as many as 7 plants in each experimental plot at the age of 20 and 70 DAS. Based on the results of ANOVA analysis, treatment B4 
with a dose of $75 \%$ inorganic fertilizer coated with activated charcoal showed the highest plant and had the highest number of leaves. This shows that the application of $75 \%$ dose of inorganic fertilizer coated with activated charcoal has been able to meet the needs of plants to grow the highest and produce the highest number of leaves (Table 3). According to Foth (1994) in Olvie et al. (2015) that the determination of concentration and dose in fertilization is very important because it will have an adverse effect on growth if it is not in accordance with plant needs.

Table 3 - The results of ANOVA parameters of plant height and number of leaves during field experiment in 2019

\begin{tabular}{|c|c|c|c|c|c|c|c|c|c|}
\hline Treatment & $\begin{array}{l}\text { Plant Height } \\
20 \text { DAS }\end{array}$ & Stdev & Plant Height 70 DAS & Stdev & $\begin{array}{l}\text { Number } \\
\text { of Leaves } \\
20 \text { DAS }\end{array}$ & Stdev & $\begin{array}{l}\text { Number } \\
\text { of Leaves } \\
70 \text { DAS }\end{array}$ & & Stdev \\
\hline B1 & $46,86 \mathrm{a}$ & 6,031 & $48,43 \mathrm{a}$ & 6,925 & $25,14 \mathrm{a}$ & 12,59 & 22,57 & $\mathrm{a}$ & 5,86 \\
\hline B2 & $46,43 \mathrm{a}$ & 6,768 & $46,14 a$ & 6,149 & $25,00 \mathrm{a}$ & 6,78 & 15,14 & a & 2,67 \\
\hline B3 & $48,14 \mathrm{a}$ & 3,671 & $48,29 \mathrm{a}$ & 9,482 & $27,14 \mathrm{a}$ & 5,52 & 16,43 & a & 5,38 \\
\hline B4 & 50,07 a & 6,354 & $53,00 \mathrm{a}$ & 3,000 & 35,43 a & 10,97 & 26,43 & a & 16,81 \\
\hline B5 & 49,71 a & 4,821 & $50,71 a$ & 6,651 & $31,29 \mathrm{a}$ & 7,97 & 22,57 & a & 7,85 \\
\hline
\end{tabular}

Note: The average value followed by the same letter in the same column means that it is not significantly different in the Tukey's Test 5\%.

Based on the data in Table 3, the application of activated charcoal coated rice husks in reducing the dose of inorganic fertilizer use can offset the $100 \%$ dose of inorganic fertilizer use. According to Wijayanti (2009) that mashed rice husk charcoal is recommended to be used because it has absorption speed. In a research report, Gusmailina et al. (2000) argued that the application of activated charcoal in the growing media could increase the growth of Eucalyptus urophylla better than fertilizer, but the growth would be better when the activated charcoal was mixed with compost. Lempang and Tikupadang research report (2013) stated that the growing medium for seedlings of Gmelina arborea Roxb added with activated charcoal at a level of $15 \%$ could increase the growth of $8.20 \%$ in height, $45.95 \%$ in stem diameter and $58.82 \%$ in biomass weight.

In addition to functioning as absorption, husk charcoal can increase soil $\mathrm{pH}$, thereby increasing the availability of phosphorus $(P)$. It is known that $P$ fertilizer is a macronutrient fertilizer needed by plants, including for the formation of ethriphosphate fertilizer (ATP). ATP is a fertilizer that plants need in every cell activity which includes cell division, enlargement and elongation so that the availability of $\mathrm{P}$ affects the growth of plant height. Gardner et al. (1991) stated that the increase in plant height occurred due to cell division and an increase in the number of cells that needed fertilizer in the form of ATP. Lingga and Marsono (2007) added that the main role of $\mathrm{N}$ for plants is to stimulate overall growth, especially stems, branches, and leaves. In addition, $\mathrm{N}$ plays an important role in the formation of forage leaves which are very useful in the process of photosynthesis.

Table 4 - The results of ANOVA parameter for number of shallot bulbs during field experiment in 2019

\begin{tabular}{ccccc}
\hline Treatment & $\begin{array}{c}\text { Number of Bulb } \\
\text { 20 DAS }\end{array}$ & Stdev & $\begin{array}{c}\text { Number of Bulb } \\
70 \text { DAS }\end{array}$ & Stdev \\
\hline B1 & $3,71 \mathrm{a}$ & 1,799 & $4,71 \mathrm{a}$ & 1,704 \\
B2 & $4,14 \mathrm{a}$ & 1,952 & $3,29 \mathrm{a}$ & 0,756 \\
B3 & $4,30 \mathrm{a}$ & 1,813 & $4,86 \mathrm{a}$ & 1,676 \\
B4 & $5,57 \mathrm{a}$ & 1,512 & $6,14 \mathrm{a}$ & 3,132 \\
B5 & $5,00 \mathrm{a}$ & $5,86 \mathrm{a}$ & 2,116 \\
\hline
\end{tabular}

Note: The average value followed by the same letter in the same column means that it is not significantly different in Tukey's Test 5\%.

The availability of nutrient fertilizers in the soil that affects plant growth in this case the number of leaves, plants that do not get additional $\mathrm{N}$ fertilizer will grow stunted and the leaves are formed smaller, thinner and less in number, while plants that receive $\mathrm{N}$ fertilizer grow taller and leaves are formed more and extensive (Poerwowidodo, 1992). Charcoal has 
a lot of pores, therefore, even though it is large, it is light, and husk charcoal is no exception. These pores function to bind by absorbing nutrient fertilizers, and if nutrient fertilizers have been absorbed then when watered, nutrient fertilizers do not dissolve in water (Rudy, 2019). The nitrogen given is soluble, it is hoped that the application of activated charcoal can make the nitrogen available slowly release for plants.

Based on the results of data analysis in Table 4, it is known that the highest number of shallot bulbs was in treatment B4 with a dose of $75 \%$ inorganic fertilizer coated with activated charcoal. This shows that the addition of activated charcoal coating on inorganic fertilizers can reduce the amount of fertilizer used with yields exceeding the B1 treatment which use of full dose of inorganic fertilizers. According to Engelstad (1997) in Olvie et al. (2015), optimal application of $\mathrm{N}$ can increase plant growth, increase protein synthesis, chlorophyll formation which causes leaf color to become greener, and increase root ratio. The number of tillers greatly affects the number of bulbs in the plant. The more the number of tillers, the more the number of bulbs produced. The availability of nutrients in plants can affect the number of bulbs in plants. Pohan et al. (2002) stated that charcoal has the potential to be developed as a nutrient absorber and releaser (in fertilizers) in the field of soil fertility because it has a large surface area and is approximately the same as soil colloid. With the application of husk charcoal, it can make slowly absorbed fertilizer available to plants and make fertilizer not easily soluble in water. The high $\mathrm{pH}$ of husk charcoal increases the availability of $\mathrm{P}$ element, which is known to function as $P$ to form flowers, fruit and seeds.

Table 5 - The results of ANOVA parameters of weight and weight after a shelf life of 30 and 60 Days After Harvest (DAH)

\begin{tabular}{ccccccc}
\hline Treatment & Weight $(\mathrm{kg} / \mathrm{ha})$ & Stdev & $30 \mathrm{DAH}(\mathrm{kg})$ & Stdev & $60 \mathrm{DAH}(\mathrm{kg})$ & Stdev \\
\hline B1 & $2271,3 \mathrm{a}$ & 311,1 & $1303,3 \mathrm{~b}$ & 292,9 & $1146,7 \mathrm{~b}$ & 290,4 \\
B2 & $2475 \mathrm{a}$ & 677,7 & $1826,7 \mathrm{a}$ & 210,8 & $1700 \mathrm{a}$ & 191,1 \\
B3 & $2855 \mathrm{a}$ & 271,2 & $1838,3 \mathrm{a}$ & 162,6 & $1723,3 \mathrm{a}$ & 213,9 \\
B4 & $2927,7 \mathrm{a}$ & 282,7 & $1955 \mathrm{a}$ & 39,1 & $1815 \mathrm{a}$ & 35 \\
B5 & $2416,7 \mathrm{a}$ & 4,575 & $1876,7 \mathrm{a}$ & 157,5 & $1758,3 \mathrm{a}$ & 151,8 \\
\hline
\end{tabular}

Note: The average value followed by the same letter in the same column means that it is not significantly different in Tukey's 5\% Test.

With a high $\mathrm{pH}$ value of activated charcoal that increases the availability of $\mathrm{P}$. Rinsema (1986) states that phosphorus is very influential in growth and yield formation, where phosphorus functions in energy transfer and the photosynthesis process. The availability of phosphorus in sufficient quantities at the beginning of growth will affect the productive parts of the plant, especially in fruit formation, because at this phase, an adequate supply of $P$ nutrients is needed.

Table 5 shows that the storage weight of shallot bulbs at 30 and $60 \mathrm{DAH}$ was highest in the B4 treatment, i.e. the dose of inorganic fertilizer was $75 \%$ coated with activated charcoal. Pangaribuan (2008) in Zulyana (2011) states that the dry weight of plants will increase if photosynthesis increases, so that biomass will be absorbed along with the photosynthesis process. The amount of biomass absorbed will affect the high and low dry weight of the plant. Sudrajad (2015) stated that the total dry weight of plants is a reflection of the accumulation of organic compounds that have been successfully synthesized by plants from inorganic compounds (nutrients, water, and carbon dioxide). Pahan (2008) argued that a good crop fertilization strategy must refer to the concept of maximum effectiveness and efficiency including: the type of fertilizer, the time and frequency of fertilization and the method of applying fertilizer. The addition of husk charcoal coating has an effect on the vegetative and generative growth of plants. The correlation of plant growth is influenced by the availability and distribution of food in other parts of the plant, the use of more water or nutrients in a part of the plant, the presence of growth regulators, or the formation of certain substances in plants (Darmawan and Baharsjah, 2010). 


\section{CONCLUSION}

Based on the results of the field experiment, it can be concluded that the application of inorganic fertilizers as much as $75 \%$ of the standard dose plus activated charcoal coated can give the highest effect on plant height, number of leaves, number of bulbs, yields and weight of shelf life 30 to 60 days after harvesting.

\section{CONFLICT OF INTERESTS}

Authors clearly declare that they have no competing interests.

\section{CONTRIBUTORSHIP}

Both authors, Titin Sugianti and Baiq Nurul Hidayah, contributed equally during the field experiment and in the process of preparing and publishing this paper.

\section{ACKNOWLEDGEMENTS}

The authors would like to thank all staff at the IP2TP Sandubaya Research Station West Nusa Tenggara Assessment Institute for Agricultural Technology for all their assistance during the field experiment in 2019.

\section{REFERENCES}

1. Anonymous. (2016). Laporan Kinerja Badan Penelitian and Pengembangan Pertanian. http://www.litbang.pertanian.go.id/lakip/2016/lakin_balitbangtan_2016.pdf. Accessed 23 April 2018.

2. Darmawan, J. and J. S. Baharsjah. (2010). Dasar-dasar Fisiologi Tanaman. SITC. Jakarta.

3. Eka Pratama. (2017). Pengaruh Pemberian Kompos and Arang Aktif dari Hasil Pengolahan Sampah Pasar Terhadap Pertumbuhan and Produksi Cabai Merah (Capsicum annuum Linn.). Jom Faperta Vol.4 No.1 Februari 2017.

4. Fajar Prayogi, Islan and Erlida Ariani. (2019). Pertumbuhan and Hasil Bawang Merah (Allium ascalonicum L.) pada Beberapa Jenis Medium Tanam dengan Teknik Vertikultur. JOM FAPERTA Vol. 6 Edisi 1 Januari s/d Juni 2019.

5. Firmansyah, M. A. \& M. S. Mokhtar. (2014). Kisah Sukses Merintis Pengembangan Bawang Merah di Kalimantan Tengah. Balitbangtan, Jakarta. 58 pp.

6. Gardner, F. P., R. B. Pearce and R. L. Mitchell. (1991). Fisiologi Tanaman Budidaya. Terjemahan Herawati Susilo. Universitas Indonesia Press. Jakarta.

7. Gunaris. (2018). Pengaruh Cara and Dosis Aplikasi Pupuk Silikat Cair Terhadap Pertumbuhan and Hasil Bawang Merah (Allium ascalonicum L.). Skripsi, Universitas Mataram.

8. Gusmailina, G. Pari, S. Komarayati. (2000). The Utilization Technology on Charcoal as a Soil Conditioning [Project Report]. Forest Products Research Centre. Bogor.

9. Gusmailina, Sri K., and Gustan P. (2015). Membangun Kesuburan Tanah dengan Arang. Pusat Penelitian and Pengembangan Hasil Hutan. 63 pp.

10. Hesti Wijayanti. (2009). Karbon Aktif dari Sekam Padi (Pembuatan and Kapasitasnya untuk Adsorpsi Larutan Asam). Info Teknologi Volume 10 No. 1 Juli 2009 (61-67).

11. Dahlianah I. (2018). Pemanfaatan Arang Aktif sebagai Komponen Media Terhadap Pertumbuhan and Produksi Tanaman Selada (Lactuca sativa L.). Jurnal IImiah Matematika and IImu Pengetahuan Alam, Volume 15 No. 1 Juni 2018 DOI 10.31851/sainmatika. v15i1.1767. 
12. Lempang, M. and H. Tikupadang. (2013). Aplikasi Arang Aktif Tempurung Kemiri Sebagai Komponen Media Tumbuh Semai Melina. Jurnal Penelitian Kehutanan Wallacea 2 (2): 121-137. Balai Penelitian Kehutanan Makassar, Makassar.

13. Lingga, P. and Marsono. (2007). Petunjuk Penggunaan Pupuk. Penebar Swadaya. Jakarta.

14. Nainggolan, Ganda Darmono, Suwardi, and Darmawan. (2009). Pola Pelepasan Nitrogen dari Pupuk Tersedia Lambat (Slow Release Fertilizer) Urea-Zeolitasam Humat. Prosiding Seminar Nasional Zeolit IV Bandung: 2-4 November 2009.

15. Olvie G. Tandi, Jeanne Paulus and Arthur Pinaria. (2015). Pertumbuhan and Produksi Bawang Merah (Allium ascalonicum L.) Berbasis Aplikasi Biourine Sapi. Eugenia Volume 21 No. 3 Oktober 2015. Hal $142-150$.

16. Pahan I. (2008). Panduan Lengkap Kelapa Sawit. Manajemen Agribisnis dari Hulu Hingga Hilir. Penebar Swadaya. Jakarta.

17. Poerwowidodo. (1992). Telaah Kesuburan Tanah. Angkasa. Bandung.

18. Pohan et al. (2002). Pengaruh Suhu and Konsentrasi Natrium Hidroksida pada Pembuatan Karbon Aktif and Sekam Padi. Balai Pengembangan Khemurgi and Aneka Industri. Balai Besar Penelitian and Pengembangan Industri Hasil Pertanian. Departemen Perindustrian and Perdagangan. Jakarta.

19. Pratomo, K. R., Suwardi, and Darmawan. (2009). Pengaruh Pupuk Slow Release Ureazeolit-Asam Humat (UZA) terhadap Produktivitas Tanaman Padi var. Ciherang. Jurnal Zeolit Indonesia 8 (2): 83-88.

20. Restiana, M., Maya D., and Benny J. (2017). Pengaruh Pupuk Kombinasi Urea - Zeolit Arang Aktif (UZAA) Terhadap $\mathrm{pH}$, Eh, Amonium and Nitrat pada Tanah Sawah Rancaekek, Kabupaten Bandung. Soilrens, Volume 15 No. 2, Juli - Desember 2017.

21. Rinsema, W. J. (1986). Pupuk and Cara Pemupukan. Bhratara Karya Akara. Jakarta.

22. Rudy Trisnadi. K. (2019). Manfaat Arang Sekam untuk Pertanian. http://dkpp.probolinggokab.go.id/wp-content/uploads/2019/08/Web.Arang-Sekam2019.pdf. 24 April 2020.

23. Sudrajad D. (2015). Teknik Penaburan Benih Secara Langsung sebagai Metode Alternatif Rehabilitasi Hutan. Seminar Nasional. Yogyakarta.

24. Suriadi A. (2018). Laporan Akhir Perakitan and Pengembangan Paket Teknologi Hemat Air and Ramah Lingkungan Budidaya Bawang Merah di Lahan Kering NTB. BPTP NTB, Mataram.

25. Zulyana. (2011). Respon Mentimun terhadap Pemberian Dosis Pupuk. (Skripsi). Program Studi Agronomi Fakultas Pertanian Universitas Negeri Sebelas Maret. Surakarta. 